\title{
PRELIMINARY STUDIES ON THE DEVELOPMENT OF LIME-BASED MORTAR WITH ADDED EGG WHITE
}

\author{
Md Azree Othuman Mydin ${ }^{1 *}$ \\ ${ }^{1}$ School of Housing, Building and Planning, Universiti Sains Malaysia, 11800, Penang, Malaysia
}

(Received: May 2017 / Revised: August 2017 / Accepted: October 2017)

\begin{abstract}
Lime is among the binding agents used in binding masonry units, such as brick, in many historical buildings around the world. Its physical strength, mechanical strength, and durability properties, as well as its raw material composition, can play substantial roles in the structural behavior of historic buildings. The production technologies may also differ according to their specific use in the structural layout. Hence, the characteristics of lime mortars are of interest in the assessment of the structural characteristics of historic buildings. In addition, the determination of characteristics of lime mortars is also important for the production of intervention mortars to be used in the restoration of historic buildings. This research focused on the effects of egg white on lime mortar's physical and mechanical properties. Five mixes were prepared by maintaining a constant lime-sand-water ratio of 1:2:0.035. As the binder material, the control mixture comprised only lime putty, while various percentages of egg white in the range of $2-10 \%$ were used to prepare the remaining mixtures. An experiment was then performed with different percentages of egg white to examine the lime mortar's axial compressive and flexural strength, as well as the water absorption. The results indicated that the compressive and flexural strength of the lime mortar increased with the increasing percentage of egg white added into lime mortar until the mixture reached $6 \%$ egg white. The addition of $8 \%$ and $10 \%$ egg white made the compressive and flexural strength start to decrease. Lime mortar that contains $6 \%$ egg white had the highest compressive and flexural strength compared to the other mix design groups. The axial compressive strength and bending strength of lime mortar can also be influenced by the air pores.
\end{abstract}

Keywords: Compression test; Egg white; Flexural test; Lime mortar; Lime putty; Water absorption; Workability

\section{INTRODUCTION}

Traditionally, ordinary lime has been one of the most significant binder materials, and initial instances of its use have been found in Tunisia, Palestine, Oman, and Turkey. Toward the middle of the $18^{\text {th }}$ century, hydraulic limes started to supplant ordinary lime mortars, and the use of lime had diminished with the expansion of Portland cement material in the 19th century (Lubelli et al., 2011). This tendency was indeed nurtured by problems experienced concerning the utilization of lime mortars, comprising elongated setting and hardening times, particularly at very high relative humidity $(\mathrm{RH})$; low internal cohesion; weak mechanical properties; and high porosity. These attributes make lime mortar vulnerable to destruction caused by the salt contamination when saturated with water (Andrew, 2005). At present, lime is frequently

\footnotetext{
*Corresponding author's email: azree@usm.my, Tel: +604-6533888, Fax: +604-6589666 Permalink/DOI: https://doi.org/10.14716/ijtech.v8i5.442
} 
employed for restoring and conserving historic buildings, and it has become a chief material. Furthermore, its characteristics make it highly suitable and long-lasting building materials; as a result, it has been used in mortars, paints, and plasters for centuries. It has many favorable properties that make it optimal for use in masonry restoration. Lime mortars exhibit antifungal properties, high mechanical resistance and better waterproof protection in comparison to normal strength concrete, epoxy, cast stone, cast aluminum and glass fiber reinforced polymer. Unlike the framed structures with masonry veneers currently being built, traditional masonry structures used to be only solid masonry (Groot, 2012). The wall thickness would provide strength and keep moisture out of the living space. This was accomplished using plasters, lime mortars, and paints (lime wash), as lime has the capacity to absorb large water quantities and can easily release the moisture back into the atmosphere due to its porosity. Replacing the historic limebased materials with modern materials could cause a lock-in of moisture in the walls, thereby leading to many complications, including interior water damage, masonry unit failure, and structural failure of the interior wall's wythes (Hughes, 2012).

Traditional materials, such as Roman mortar, lime mortar, and natural cement, are optimum, and thus recommended, as they exhibit features like suitable strength in ancient buildings and good compatibility. They are considered more effective than modern materials, as established via modern research and history. When used in mortars, lime provides the benefit of higher bond strength compared with unmodified non-lime mortars. In addition, the particle size of lime is much smaller when compared with other common mortar binders. Thus, it can more effectively bond with and fill in the pores of stone/brick. Moreover, the addition of airentraining agents, which result in the formation of bubbles and reduce the surface area contact between the brick/stone and the mortar, is not necessary, as lime creates creamier mortars. However, a few challenges prevail in the use of traditional lime materials. The curing process of lime is different in terms of duration, compound, relative humidity and temperature, in which it follows various mechanisms when compared with modern materials. Adverse weather conditions may also influence the process. Sometimes, even experienced masons and craftspeople that deal with modern materials face problems when installing lime materials. A schematic overview of lime processing and the resulting materials is presented in Figure 1.

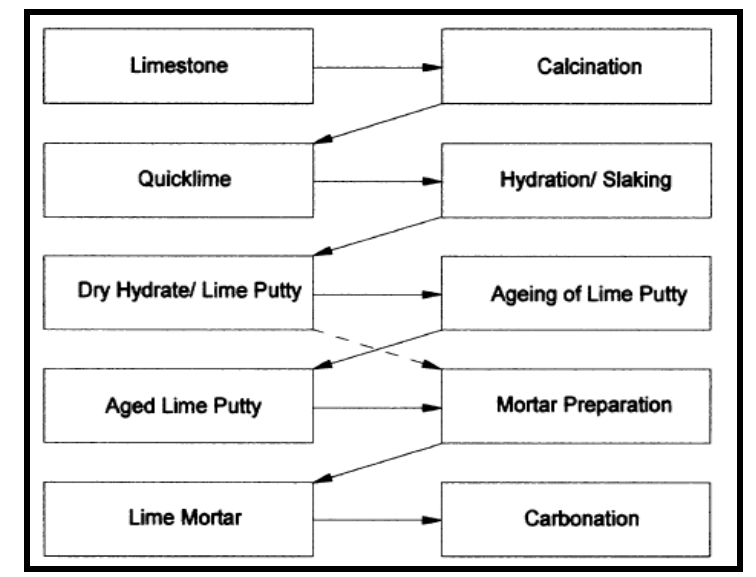

Figure 1 Schematic overview of lime processing and resulting materials (Javadpour et al., 2002)

It should be noted that slaked lime will set gradually and lose water through the process of evaporation; moreover, will absorb carbon dioxide from the air, thereby changing back from calcium hydroxide, $\mathrm{Ca}(\mathrm{OH})_{2}$, to calcium carbonate, $\mathrm{CaCO}_{3}$. Once slaked, the oxide from the lime component will combine with water and become hydroxide, also called hydrated lime. During the setting stage, the calcium hydroxide loses its water via the evaporation process, and it will then absorb carbon dioxide from the air, becoming $\mathrm{CaCO}_{3}$ once again. 

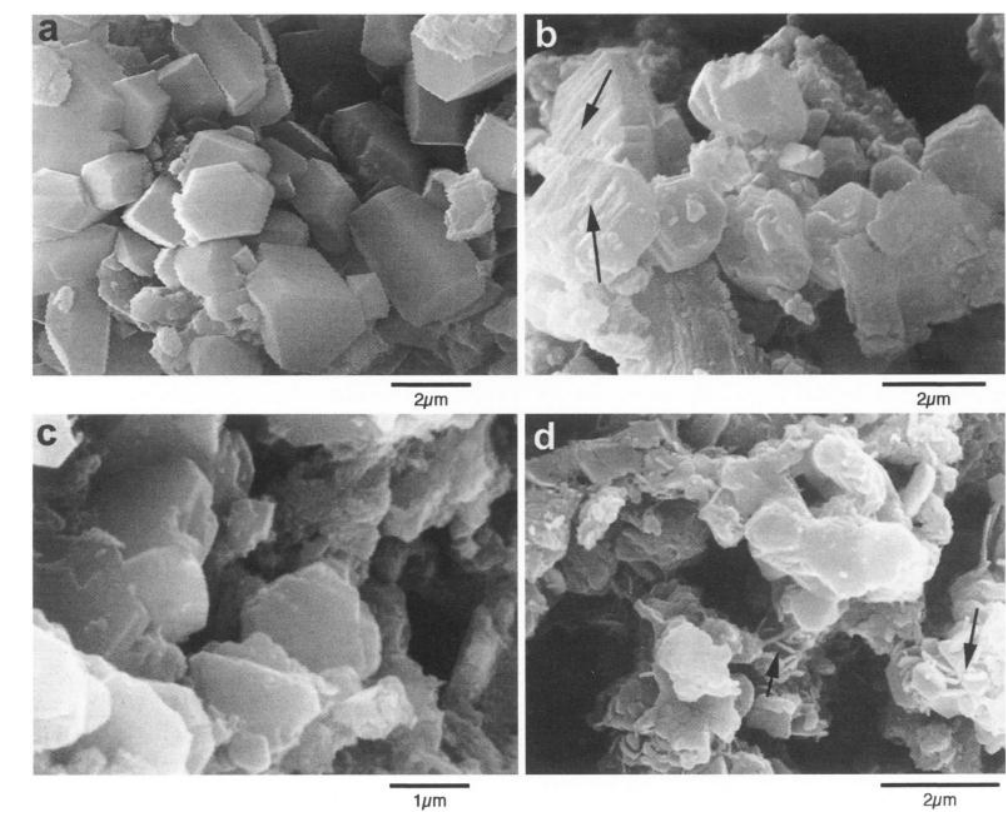

Figure 2 Scanning electron microscopy (SEM) analysis: (a) prismatic portlandite crystals generated due to hydration; (b) prismatic portlandite crystals generated due to the corrosion process along the prismatic faces; (c) abundance of portlandite crystals; (d) subordinate submicrometer plate-like crystals established in the $\mathrm{Ca}(\mathrm{OH})_{2}$ matrix

Javadpour et al. (2002) carried out a study to compare the size of fresh and aged lime putties, as well as their crystal morphology, using several analytical methods to elucidate the consequences of protracted storage under water on the calcium hydroxide. The lime putties were made from calcium oxide (referred to as Sample A) and a traditionally prepared quicklime (referred to as Sample B). Both lime putties were slaked under unremitting stirring, using a lime to water ratio of $1: 3$, with the water at room temperature. By means of the X-ray diffraction (XRD) and scanning electron microscopy (SEM) methods, the researchers established that in both lime putties, prismatic calcium hydroxide crystals (Figure 2a) underwent significant size reduction (from $>2$ to $<1 \mu \mathrm{m}$ ) and a substantial morphological transformation. This was due to the greater solubility of the prism faces of the hexagonal portlandite, $\mathrm{Ca}(\mathrm{OH})_{2}$, crystals, which became corroded during the aging process (Figure 2b), while the basal faces were unspoiled (Figure 2c). Simultaneously, subordinate nucleation of plate-like, nanoscale portlandite crystals was detected, as shown in Figure 2d.

For conservation repair work, a prior understanding and know-how regarding the building or structure is essential before undertaking any work. This is especially true and important for lime-based works. Sometimes, the original mortar may contain inherent defects. In addition, over time, buildings and their surrounding environments may not remain the same. For example, a building that was previously residential may now be a roofless ruin. To match the new performance requirements, repair mortars may require a different design from the original mortars. This study involves the addition of an organic material (egg white) to lime mortar to modify its properties.

\section{BACKGROUND OF THE STUDY}

Currently, a revitalization of lime mortar utilization for repairing historical buildings is taking place, owing to the unfavorable properties of Portland cement, including its high thermal expansion coefficient, brittleness, and high strength. The very low porosity and large size of pores may delay water movement in masonry and lead to deterioration owing to the buildup of moisture in the cement matrix, as well as evaporation of salts in neighboring bricks. 
Furthermore, calcium sulfates and sodium salts may be present in the cement matrix, which can leach out over time (Naceri \& Chikouche Hamina, 2008). Moreover, this material has a low efflorescence potential owing to its comparatively high chemical purity. In contrast, it has the benefit of allowing limited movement in the mortar joints and can endure autogenous healing due to the disbanding and sleet processes. Figure 3 demonstrates the process of the dry slaking of lime using the minimum percentage of water, while Figure 4 visualizes the process of preparing the hot lime by embedding burned limestone in the sand matrix.

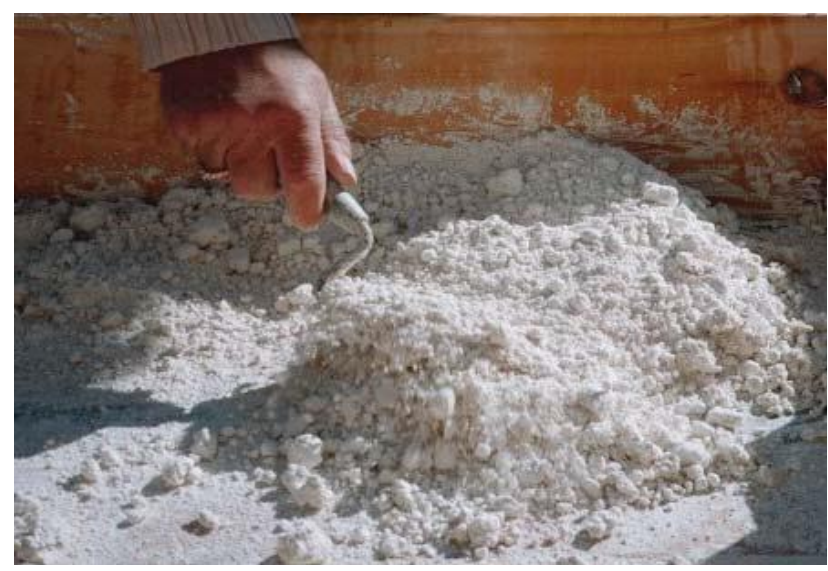

Figure 3 Process of the dry slaking of lime

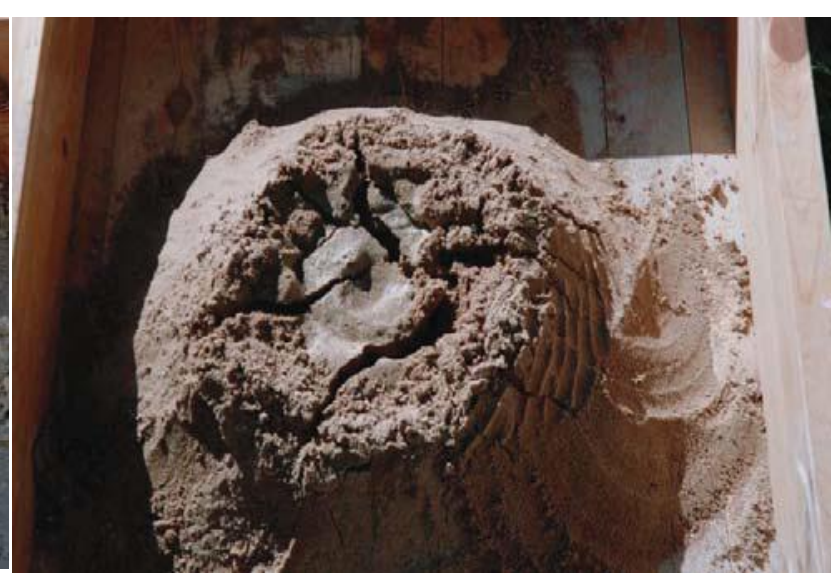

Figure 4 Process of making hot lime

For most historical masonry buildings, lime was the common universal binding material in works involving plastering and mortars. One of the many reasons for its wide-scale application was that it allows buildings to breathe (Snow \& Torney, 2014). As lime is permeable to vapor, it helps to mitigate the risks of trapped moisture and protects the building fabric from damage. In addition, its porous nature (in open-textured materials like lime plaster) offers a comfortable environment. Lime can release and absorb moisture to stabilize the building's internal humidity. It also helps to lower mold growth (Lubelli et al., 2011) and surface condensation. The growing awareness of the use of lime mortar for repair works concerning historical buildings and structures has led to plentiful research projects, predominantly concerning the properties and characteristics of mortars in connection with their constituents, potential admixtures, and numerous mixing ratios. Figure 5 shows the process of wet lime slaking, in which surplus water is added to burned lime.

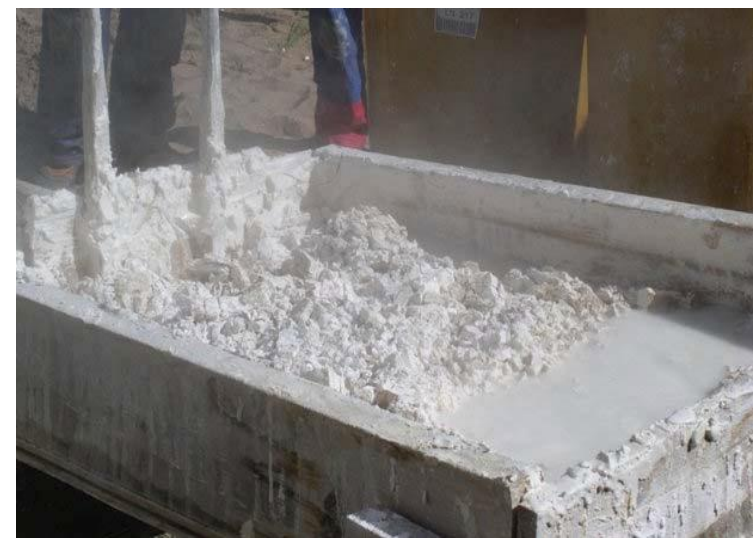

Figure 5 Process of lime slaking

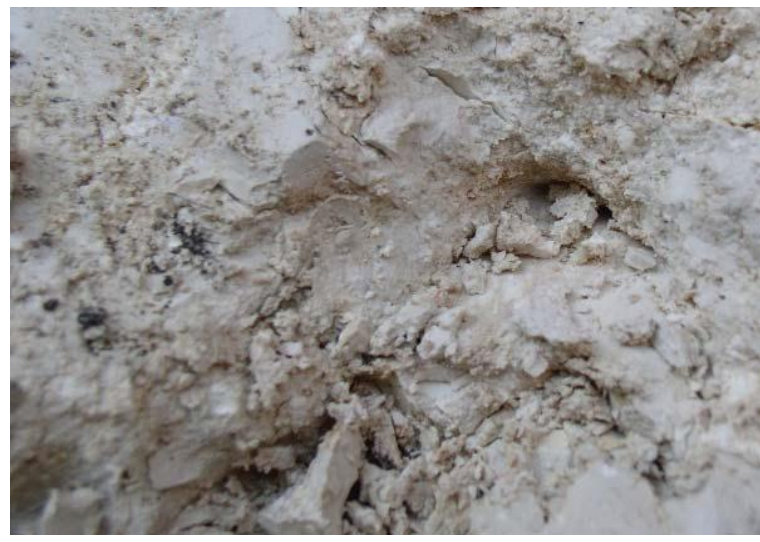

Figure 6 Earth slaked lime with a very firm consistency 
During construction, the role of fresh mortar is crucial, but it is also complex. The mortar should be easy to spread and remain workable for sufficient time to allow accurate lying to the level of the masonry units and the line. In addition, it should retain water to avoid the drying out or rapid stiffening of the walls, especially when absorbent masonry units are employed. As a result, the hardening should follow within a reasonable timeframe to avoid squeezing effect or deformation. As can be seen in Figure 6, the lime has a dry consistency before it has been whipped.

The internal friction and retention of water content determine the workability of lime mortar. These factors influence its flexural and compressive strengths, which in turn, define a mortar's overall quality and durability. The primary factor in workability is the water content, which directly defines the mortar's initial flow (Naceri \& Chikouche Hamina, 2008). For example, a large flow value can be achieved with a mortar with higher water content than the same mortar with less water content. Lime mortar regulates the movement of moisture through the building, as it has high porosity and is highly permeable. This also allows it to protect other materials, such as masonry materials, from harmful salts. As lime allows the walls to breathe, it makes people inside the buildings more comfortable. In addition, it helps in drying out the building and avoids condensation problems. All these factors depend on the permeability and highporosity characteristics of lime mortars (Andrew, 2005). Figure 7 shows a schematic diagram of the cement-hardening process. During the reaction with water, the cement particles grow, and due to this phenomenon, cement fills up the aggregate over time. The particles are mixed with water, and after a few hours, the binding starts to take place. After several months, a more compact and rigid structure is formed.

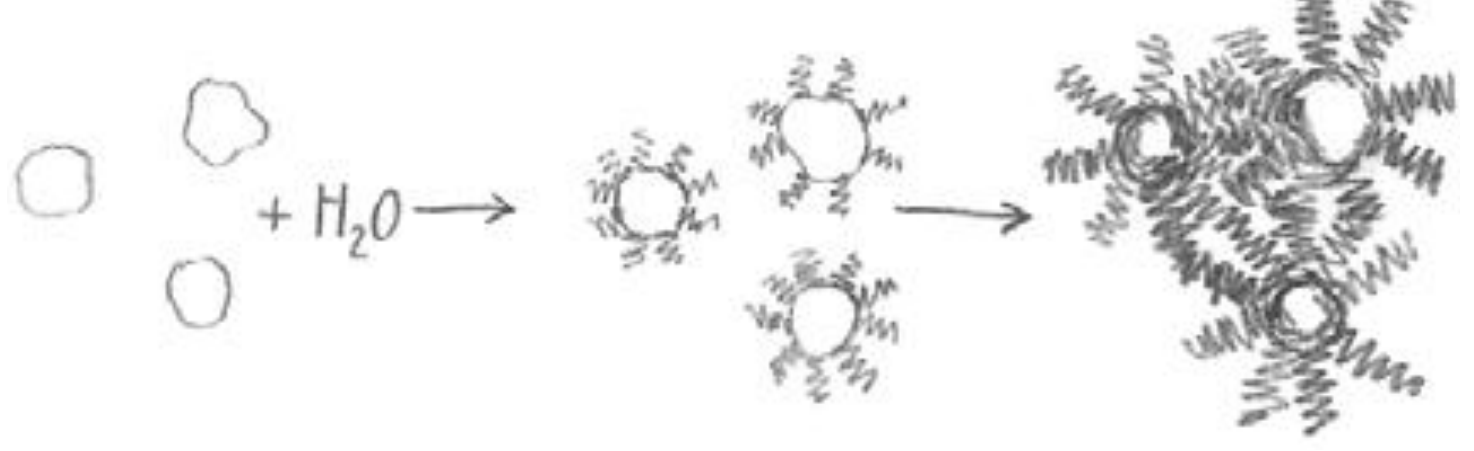

Figure 7 Process of cement hardening (Andrew, 2005)

Albumen is popularly known as egg white. Based on the egg size, $58-60 \%$ of the egg's weight is represented by egg white, which consists of $12 \%$ dry matter (primarily protein) and $88 \%$ water. A large egg's white portion comprises almost 17 calories and no cholesterol. The egg white can be categorized into three parts - the inner liquid layer, outer liquid layer, and a liquid layer of thicker consistency. It stops bacteria from penetrating the yolk. Egg white is generally alkaline, and it contains nearly 40 different proteins (Shafabakhsh \& Ahmadi, 2016). Egg contains a high protein percentage, which is made up of amino acids, and this may affect the properties of cement. Egg white can act as a powerful binding agent in food because of its high protein concentration; proteins tend to bind together, as they are slightly elastic in nature. The structure of an egg is presented in Figure 8.

\section{MATERIAL PREPARATION AND TEST SETUP}

Materials used in the experiment included the following: lime putty manufactured by the Great Lime Factory Co. Ltd., egg white, and normal fine sand. Only the egg albumen, which is the clear or misty substance that surrounds the yellow yolk, was used, since this is the part of the 
egg that contains different types of proteins, which are mostly composed of amino acids. The egg was beaten until foamy to increase its ability to mix with the mortar mixture.

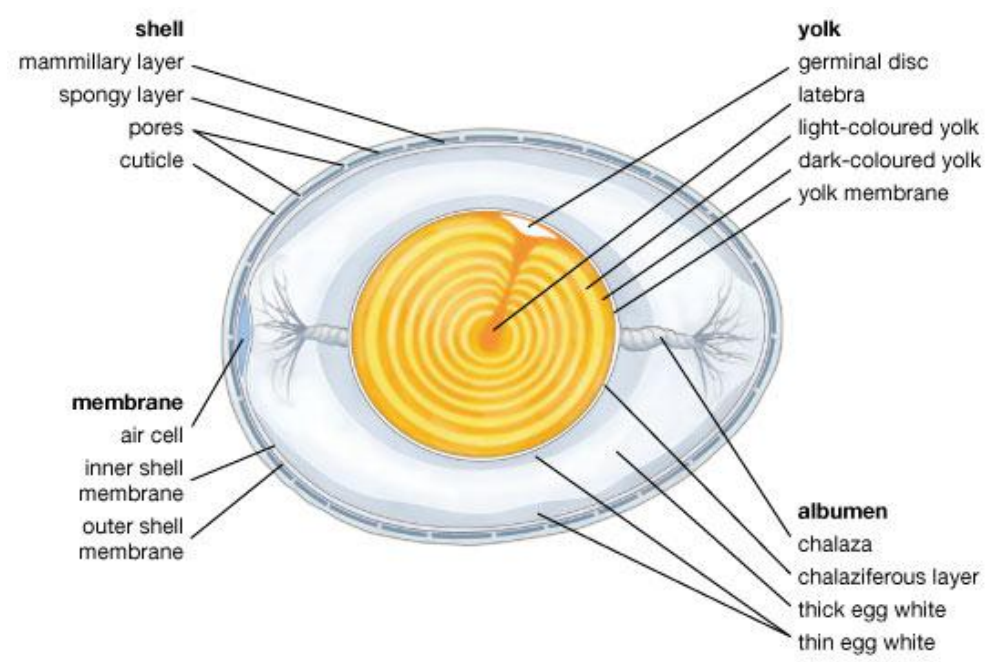

Figure 8 Typical composition of an egg

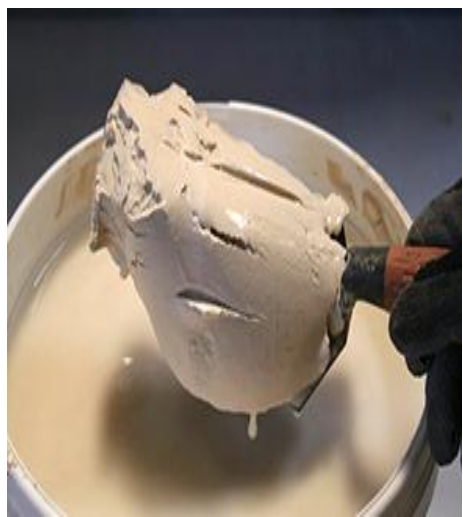

(a)

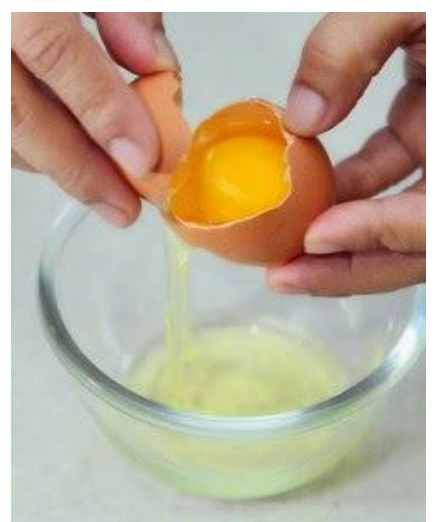

(b)

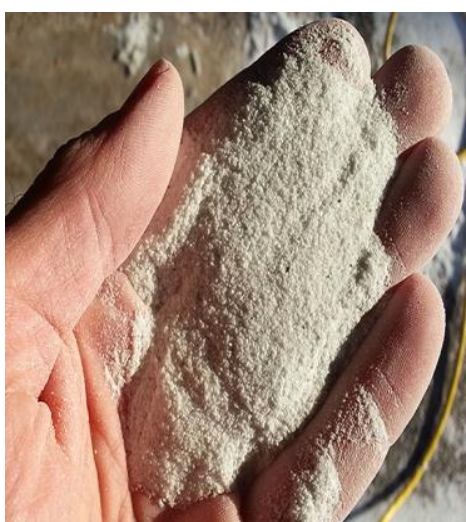

(c)

Figure 9 Materials used: (a) lime putty; (b) albumen (egg white); (c) fine sand

Hardening of the mortars was studied using standard mortar prisms $(40 \times 40 \times 160 \mathrm{~mm})$, which were prepared in accordance with the European standard (EN 196-1). Mortars were cured under standard laboratory conditions $\left(20^{\circ} \mathrm{C}, 60 \% \mathrm{RH}\right)$. The hardening progress was studied by means of mechanical strength tests. These tests were carried out by determining the compressive strength and three-point bending using the standard mortar prisms at 7, 14, 21, and 28 days of hardening (EN 196-1). The mixing proportion adopted was lime putty:egg white:fine sand:water. There were five egg white solutions used, which were $2 \%, 4 \%, 6 \%, 8 \%$, and $10 \%$. All the samples were mechanically mixed in a laboratory using a mortar mixer. Subsequently, the samples were mechanically compacted into prism molds using a vibration table. These samples were compacted into three layers (ASTM C348-97, 1997). All the specimens were left to cure in the molds for at least 24 hours prior to de-molding, at which point, they were airdried until they reached the stage when they were suitable for carrying out the tests. The workability of the fresh lime mortars with different percentages of egg white were then tested (BS EN 1015-3, 1999). Next, flexural strength was tested following ASTM C348-97 after 7, 14, 21, and 28 days of curing using standard prism specimens; axial compressive strength was tested according to ASTM C349-97 after 7, 14, 21, and 28 days of curing using broken prisms. 
In addition, water absorption tests were carried out at 7, 14, 21, and 28 days after the specimens had been stored in the oven for 3 days.

\section{RESULTS AND DISCUSSION}

The results were obtained from the experimental programs of testing the flexural strength and compressive strength of the lime mortar containing different percentages of egg white. Before the flexural and compression tests, the testing of the workability of fresh mortar was carried out to study how different percentages of the egg white solution would affect the workability of the fresh mortar, and the results were recorded. Next, the water absorptions of lime mortar containing different percentages of egg white were examined.

\subsection{Fresh Workability}

Figure 10 demonstrates the results concerning the workability of fresh lime mortar. The workability of the control mix (lime mortar without any added egg white) was about $16.0 \mathrm{~cm}$. The lime mortar with $10 \%$ egg white had the lowest workability, at only $15.9 \mathrm{~cm}$. In addition, when the $2 \%, 4 \%$, and $6 \%$ egg white concentrations were added to the lime mortar, the mortar consistencies increased to $16.3 \mathrm{~cm}, 16.6 \mathrm{~cm}$, and $16.8 \mathrm{~cm}$, respectively.

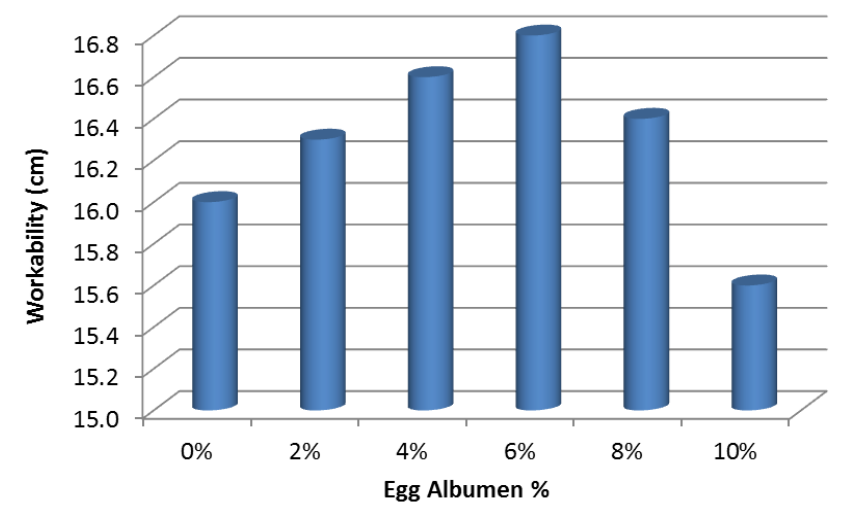

Figure 10 Workability of lime mortar with different percentages of egg white

However, when $8 \%$ and $10 \%$ egg white mixtures were added to the lime mortar, the consistency of the lime mortar started to decrease, with a resulting workability of less than $16.8 \mathrm{~cm}$. This likely occurred because, as the concentration of egg white increased, the adhesive strength of the egg white solution also increased. For egg white solutions with concentrations up to $6 \%$, the lime and sand particles slid against each other more easily, as the egg white functioned as a lubricant; this made the mortar easier to spread. When the concentration reached $8 \%$, the workability result dropped due to the high adhesive strength of the egg white. This high adhesive strength meant that the lime and sand particles stuck together easily, preventing particles from sliding against one another. Under this condition, the microstructure of the lime mortar was less compacted, leading to lower compressive strength.

\subsection{Water Absorption}

Figure 11 shows the results of the water absorption test of the lime mortar with different percentages of egg white. Based on the data collected, after 30 minutes of immersion in water, the water absorption of the lime mortar decreased when the mixtures with $2 \%, 4 \%$, and $6 \%$ egg white were added after 7, 14, 21, and 28 days. However, it started to increase again with the addition of the $8 \%$ and $10 \%$ egg white mixtures. The lime mortar with $10 \%$ egg white had the highest water absorption compared to the other mixes due to its many less-compacted pores, which were more easily accessible to water than those of other egg white lime mortars. The mixture that absorbed the lowest percentage of water was the lime mortar with $6 \%$ egg white. 
The addition of the egg white decreased the capillarity by various mechanisms. It made a thin film that spread evenly over the mortar's structure, covering the grains of the binder; this resulted in decreased connectivity between the pores and limited water transport. Furthermore, the addition of the egg white changed the pore size distribution in such a way that it decreased capillary transport.

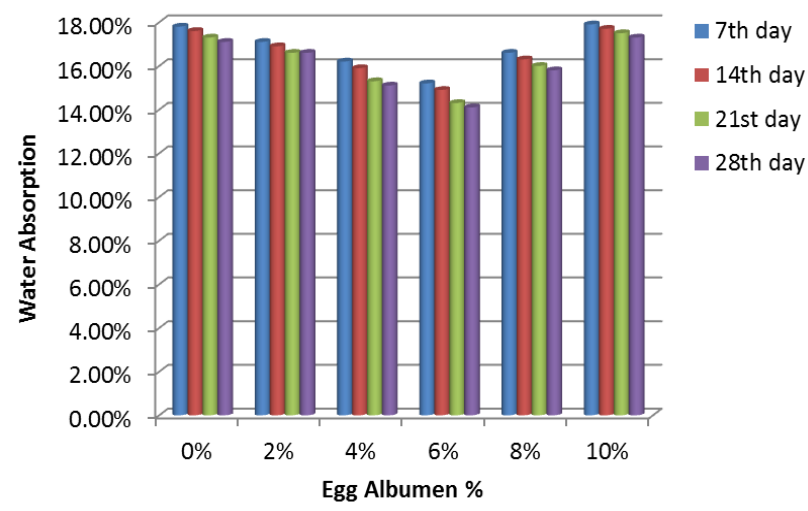

Figure 11 Water absorption of lime mortar with different percentages of egg white

\subsection{Axial Compressive Strength}

As can be seen in Figure 12, the lime mortar with the addition of 2\%, 4\%, and $6 \%$ egg white showed an increase in the compressive strength as compared to the control mix of lime mortar without egg white on days $7,14,21$, and 28 . This was due to the effects of the proteins in the egg white on the mortar. Proteins can form bonding interactions with other proteins and surfaces (Naceri \& Chikouche Hamina, 2008). This may be proved in an experiment in which egg white is spilled on two eggs and left to dry; after this occurs, it is hard to pull the two eggs apart without breaking at least one of them (Andrew, 2005). The compressive strength of lime mortar increased until the percentage of egg white reached $6 \%$. It started to fall when $8 \%$ or $10 \%$ egg white was added to the lime mortar. It can be shown that, with the addition of more egg white, the alkali content of the mortar will increase, since egg white is an alkaline solution. This may have harmful effects on the mechanical properties of aggregates that are not susceptible to alkali-silica reactions.

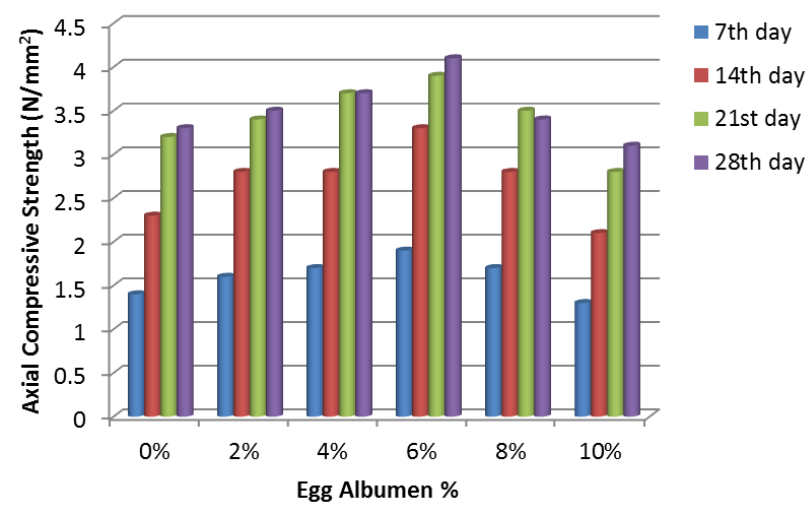

Figure 12 Axial compressive strength of lime mortar with different percentages of egg white

The compressive strength of lime mortar can also be influenced by air pores. The entrapped air pores are irregular in shape and form through the entrapment of air during the mixing process. The water content and application of the lime mortar can influence the total porosity of the mix. In addition, gravitation pores are big enough for the water to enter by gravitation force alone. 
Capillary pores in the lime mortar are filled by capillary condensation or capillary suction. Adsorption pores, which are very small, are also called gel pores; they are only present in the binder phase. Adsorption pores are filled when water molecules are adsorbed to the surface. Depending on the RH in the air, the pores can be filled with water to a greater or lesser extent according to the pore size and radius. Transportation of both gas and moisture is affected by the amount of water filling up the pores. Figure 13 shows SEM photographs of lime mortar with air pores, capillary pores, and gel pores.
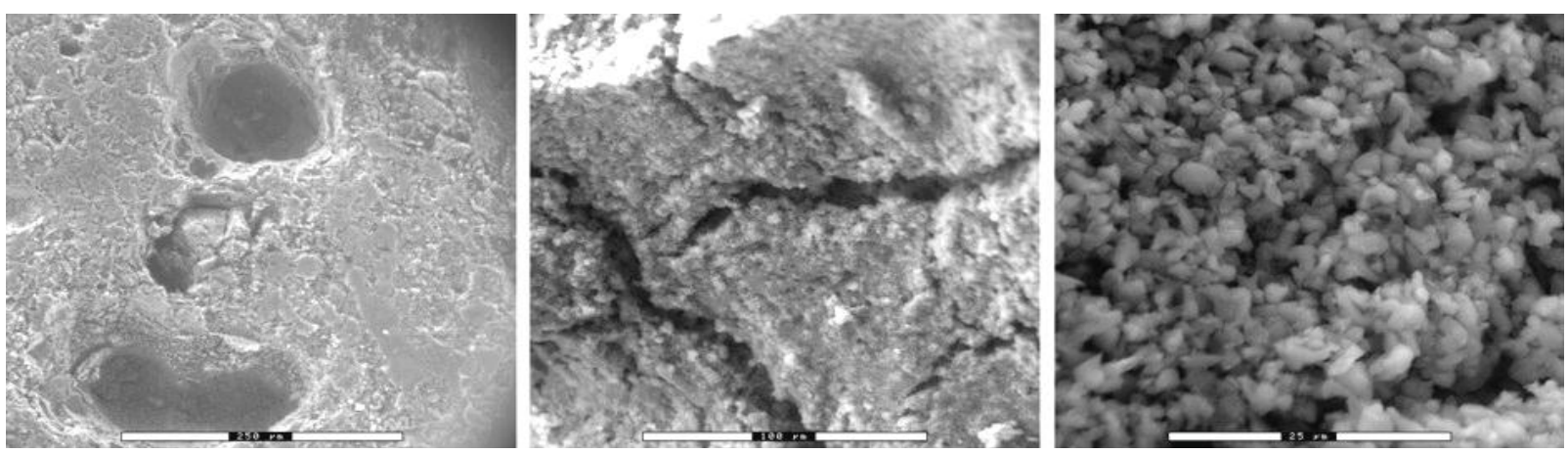

Figure 13 Electron micrographs of lime mortar, from the left: air pores, capillary pores, and gel pores. The scale bars shown, from the left, are $250 \mu \mathrm{m}, 100 \mu \mathrm{m}$, and $25 \mu \mathrm{m}$

In lime mortar, both chemically and physically bound water is present; it is the physically bound water that can be absorbed via adsorption or capillary condensation. Adsorbed water is attached to the pore walls by Van der Waals forces or several layers. In a sorption curve, the three different gradients represent three different ways for the water molecules to be absorbed inside the material-monomolecular adsorption, polymolecular adsorption, and capillary condensation.

\subsection{Bending Strength}

Figure 14 shows the results of the bending strength test. The flexural strength of the lime mortar showed increases from when $2 \%$ egg white was added to lime mortar until when $6 \%$ egg white was added at all the testing stages (including 7, 14, 21, and 28 days). The lime mortar that contained $6 \%$ egg white showed the highest flexural strength compared with the other mixtures.

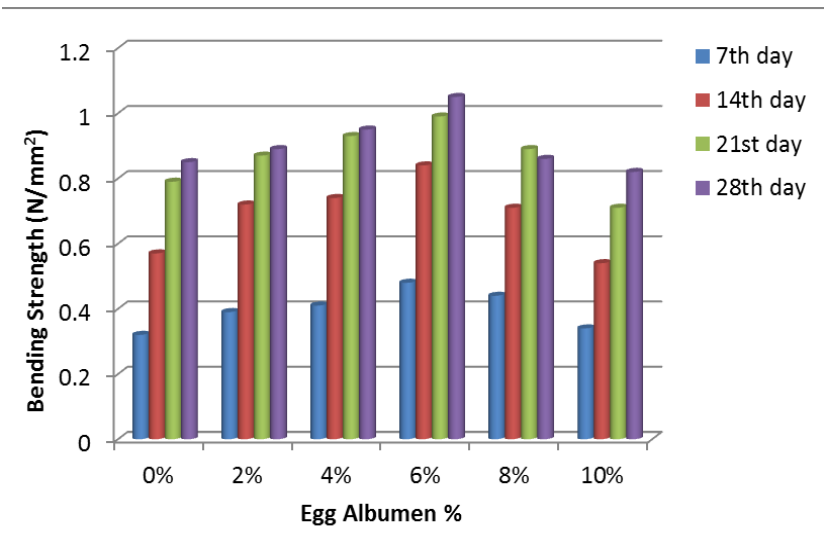

Figure 14 Flexural strength of lime mortar with different percentages of egg white

However, the flexural strength of the lime mortar started to drop after $8 \%$ or $10 \%$ egg white was added to the lime mortar. Water expands as it turns into ice crystals to avoid crack formation; there must be enough air-filled pores to allow the water to expand. At some degree 
of saturation, there will no longer be enough air, which will lead to frost damage. This is the critical degree of saturation. If the moisture content is below the critical content, the materials will endure an almost endless number of frost cycles. As soon as the critical content is passed, however, damage can occur after only one cycle.

Flexural strength can be influenced by many factors. A decrease in the strength of lime mortars can be caused by the formation of micro-cracks due to a drop in humidity in the room where the specimens are stored (Hayri, 2013). According to the recorded results, the lime mortar with 6\% egg white had the highest flexural strength, while the lime mortar with $10 \%$ egg white was the weakest mixture.

\section{CONCLUSION}

This study was conducted to examine the mechanical and engineering properties of lime mortar with the addition of different percentages of egg white. Based on all the data obtained from the laboratory investigations on lime mortar mixes with various percentages of egg white, a few conclusions can be derived. The workability of fresh lime mortar increased when $2 \%, 4 \%$, and $6 \%$ egg white were added to the lime mortar. In contrast, the lime mortar with $10 \%$ egg white had the lowest workability. The compressive and flexural strength of the lime mortar increased with increasing percentages of egg white added to lime mortar until the mixture reached $6 \%$ egg white. Moreover, the addition of $8 \%$ and $10 \%$ egg white made the compressive and flexural strength start to decrease. Lime mortar containing 6\% egg white had the highest compressive and flexural strength compared to the other mix design groups. The axial compressive strength and bending strength of lime mortar could also be influenced by the air pores.

\section{ACKNOWLEDGEMENT}

The author would like to thank Malaysia's Ministry of Higher Education for funding this research under the Fundamental Research Grant Scheme (Grant No. 203/PPBGN/6711514), with the research title "Fundamental Study to Establish Thermal Insulation, Mechanical Properties and Fire Retardant Mechanism of Coir Fibre Reinforced Lightweight Foamcrete."

\section{REFERENCES}

Andrew, J.E., 2005. Properties of Hydraulic and Non-hydraulic Limes for Use in Construction. Napier University, School of the Built Environment

ASTM Standard C109/C109M-07, 2007. Standard Test Method for Compressive Strength of Hydraulic Cement Mortars (Using 2-in. or [50 mm] Cube Specimens). West Conshohocken, PA: ASTM International, pp. 4-8

ASTM Standard C348-97, 1997. Standard Test Method for Flexural Strength of HydraulicCement Mortars, West Conshohocken, PA: ASTM International, pp. 5-7

BSI Standard BS EN 1015-3:1999, 1999. Methods of test for Mortar for Masonry. Determination of Consistence of Fresh Mortar (by Flow Table). London: BSI, pp. 12-13

Groot, C., 2012. Repair Mortars for Historic Masonry. Performance Requirements for Renders and Plasters. Materials and Structures, Volume 45, pp. 1277-1285

Hayri, U.N., 2011. The Effect of Curing Temperature and Relative Humidity on the Strength Development of Portland cement Mortar. Scientific Research and Essays, Volume 6(12), pp. 2504-2511

Hughes, J.J., 2012. Repair Mortars for Historic Masonry. The Role of Mortar in Masonry: An Introduction to Requirements for the Design of Repair Mortars. Materials and Structures, Volume 45, pp. 1287-1294 
Javadpour, J., Hosseinzadeh, M., Marghussian, V., 2002. Effect of Particle Size Distribution and Chemical Composition on Properties of Magnesia Chromite Bricks. International Journal of Engineering-Transactions B: Applications, Volume 15(2), pp. 183-190

Lubelli, B., Nijland, T.G., Van Hees, R.P.J., 2011. Self-healing of Lime Based Mortars: Microscopy Observations on Case Studies. Faculty of Architecture, Delft University of Technology, the Netherlands. Delft, Netherlands: TNO Built Environment and Geosciences, pp. 32-36

Naceri, A., Chikouche Hamina, M., 2008. Effects of Pozzolanic Admixture (Waste Bricks) on Mechanical Response of Mortar. International Journal of Engineering-Transactions B: Applications, Volume 21(1), pp. 1-8

Shafabakhsh, G., Ahmadi, S., 2016. Evaluation of Coal Waste Ash and Rice Husk Ash on Properties of Pervious Concrete Pavement. International Journal of EngineeringTransactions B: Applications, Volume 29(2), pp. 192-201

Snow, J., Torney, C., 2014. Short Guide: Lime Mortars in Traditional Buildings, Edinburgh. National Conservation Centre, Published by Historic Scotland, pp. 3-9 